\title{
Utricularia sainthomia (Lentibulariaceae), a new remarkable carnivorous species from the lateritic plateau of northern Kerala, India
}

\author{
Biju P. ${ }^{1,4^{*}}$, Josekutty E.J. ${ }^{2,4}$, Janarthanam M.K. ${ }^{3}$ \& A. Jomy ${ }^{4}$ \\ ${ }^{1}$ Department of Botany, Government College, Kasaragod, Vidyanagar P.O., Kasaragod, Kerala - 671 123, India \\ ${ }^{2}$ Department of Botany, Government Brennen College Thalassery, Dharmadam P.O., Kannur, Kerala - 670 106, India \\ ${ }^{3}$ Department of Botany, Goa University, Goa - 403 206, India \\ ${ }^{4}$ Department of Botany, St. Thomas College, Pala, Arunapuram P.O., Pala, Kerala - 686 574, India \\ `E-mail: bijuarimba@gmail.com
}

\begin{abstract}
A new species of Lentibulariaceae, Utricularia sainthomia collected from the lateritic plateau of northern Kerala, India is described and illustrated. It is compared with similar species, $U$. malabarica Janarth. \& A.N.Henry and U. lazulina P.Taylor based on vegetative, floral and seed morphology. A key to the violet flowered species in India are provided.
\end{abstract}

Keywords: New species, Utricularia, Utricularia sect. Oligocista.

\section{Introduction}

The carnivorous genus Utricularia L. ("bladderworts", Lentibulariaceae) is widely distributed in the lateritic plateau in India. The gregarious flowering of Utricularia gives characteristic colour pattern to the plateau at the end of monsoon season. Taylor (1989) in his monograph recognized 214 species while Fleischmann (2012) reported 228 species in the world. Janarthanam and Henry (1992), in their taxonomic revision, reported 35 species in India. Since then, five more species were described form India (Yadav et al., 2000, 2005; Kumar et al., 2018; Sindhu et al., 2020).

Received: 23.07.2019; Revised \& Accepted: 10.06.2020

Published Online: 30.06.2020
During an enumeration of monsoon plants in the lateritic plateau in Kerala, the authors found several populations of an interesting Utricularia among tiny grass patches at different places in Kannur and Kasaragod districts. Detailed morphological observation and discussions with the experts revealed its novelty. Hence it is described here as a new species.

\section{Material and Methods}

Fresh specimens of Utricularia were collected from seven localities in Kannur and Kasaragod districts and examined under a stereo microscope (Olympus, Japan). Morphology of the specimens was compared with allied species. Seed characters of the new species were studied with the help of a scanning electron microscope (Sigma 300, Zeiss, USA). Herbarium specimens were prepared as per Bridson and Forman (1991). Novelty of the taxon was confirmed by critical morphological analysis of the specimens, comparison with relevant literature and on discussion with experts.

\section{Taxonomic treatment}

Utricularia sainthomia P.Biju, Josekutty, Janarth.

\& Augustine, sp. nov.

Figs. 1-3

This new species is morphologically similar to U. malabarica Janarth. \& A.N.Henry and U. lazulina P.Taylor in its 3nerved leaves, basifixed bracts, shorter peduncles, recurved fruiting pedicels (absent in U. lazulina), papillate calyx lobes 

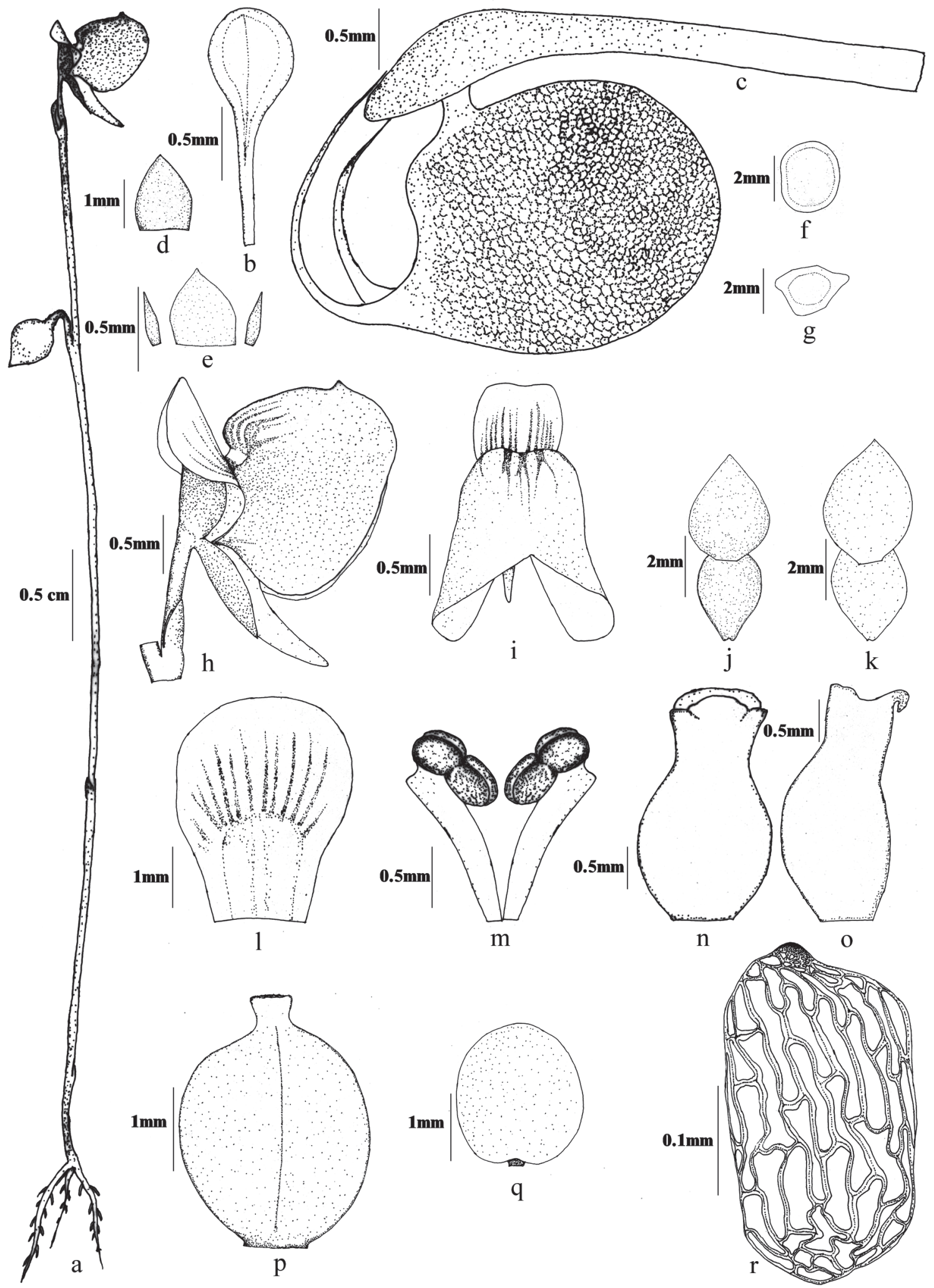

Fig. 1. Utricularia sainthomia P.Biju, Josekutty, Janarth. \& Augustine: a. Habit; b. Leaf; c. Leaf with trap; d. Scale; e. Bracts \& bracteoles; f. Transverse section of scape; g. Transverse section of pedicel; h. Flower-lateral view; i. Flower-front view; j. Flowering calyx; k. Fruiting calyx; I. Corolla-upper lip; m. Stamens; n. Pistil-adaxial view; o. Pistil-lateral view; p. Capsule; q. Placenta; r. Seed (from Biju \& Jomy 1008; drawn by P. Biju). 


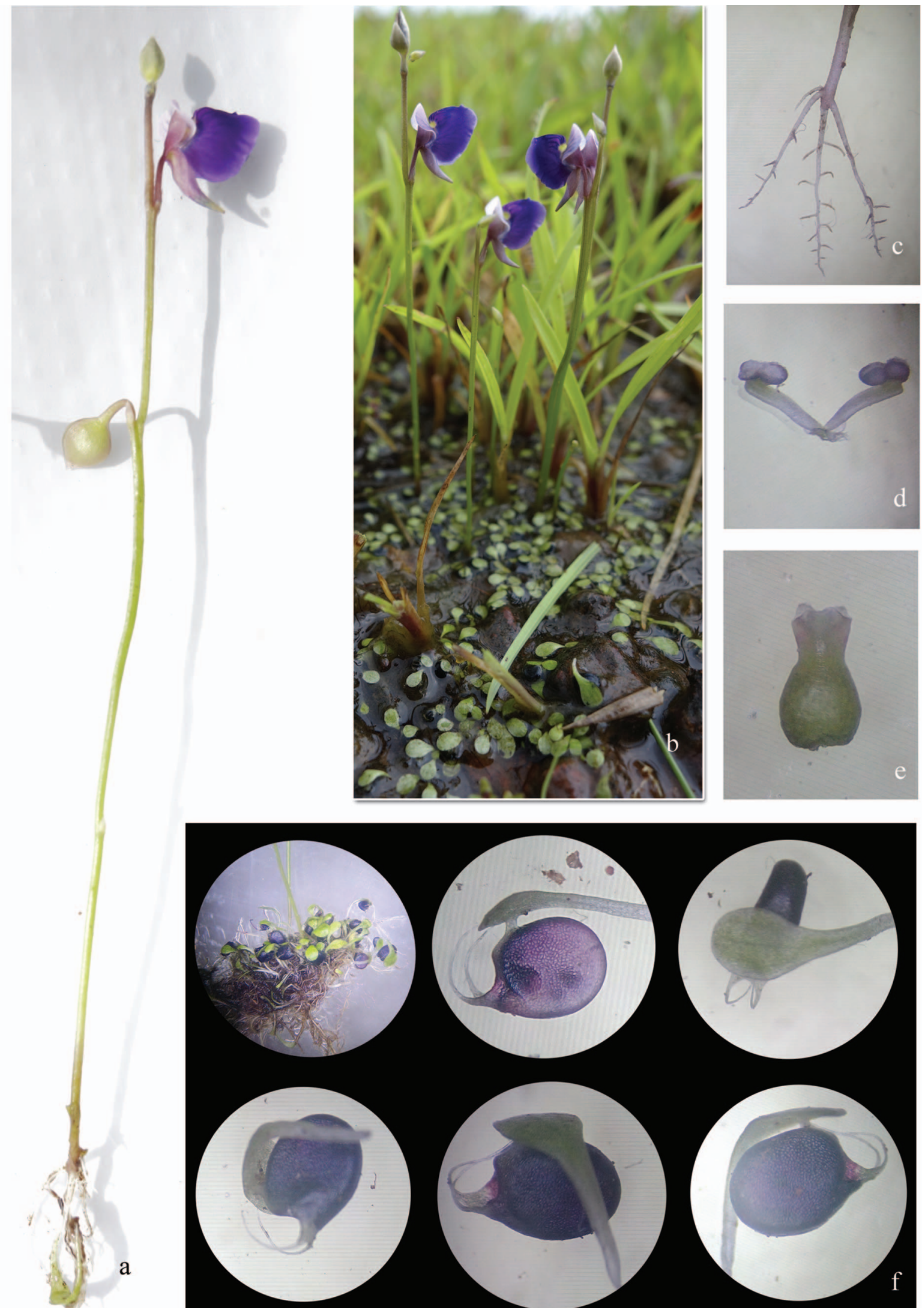

Fig. 2. Utricularia sainthomia P.Biju, Josekutty, Janarth. \& Augustine: a. Habit; b. Habitat; c. Rhizoids; d. Stamens; e. Pistil; f. Trapdifferent views (from Biju \& Jomy 1008; photos by P. Biju). 

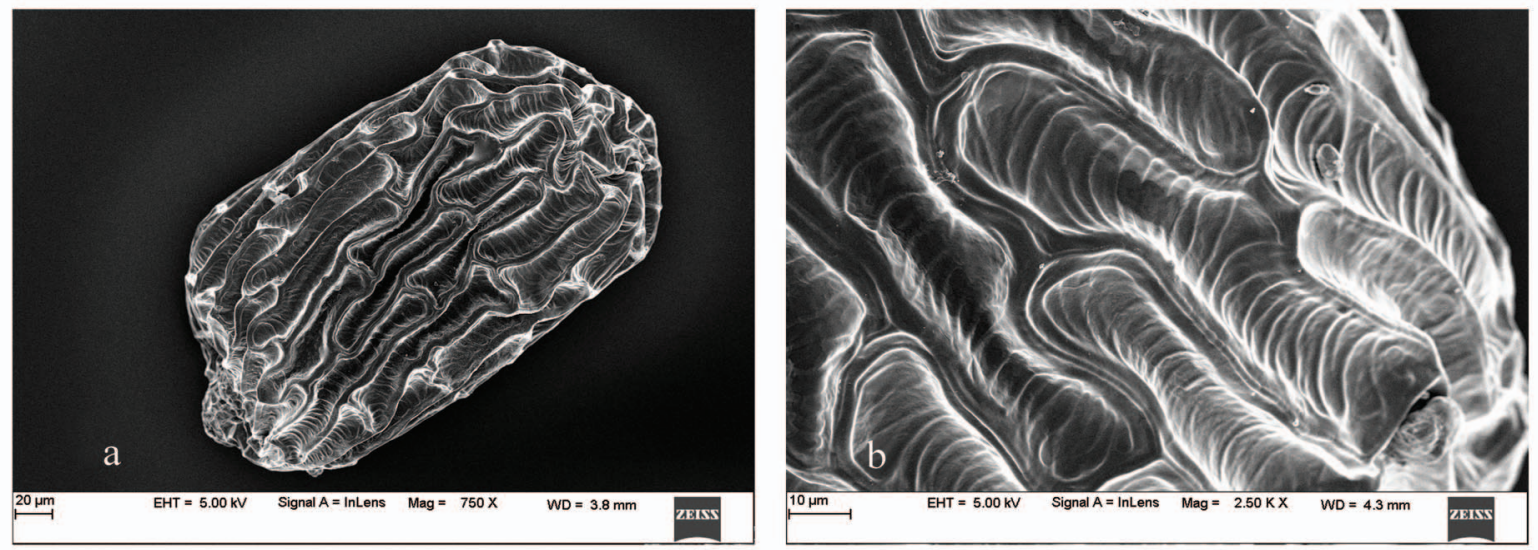

Fig. 3. Utricularia sainthomia P.Biju, Josekutty, Janarth. \& Augustine: a. Scanning electron micrograph of seed; b. Scanning electron micrograph of testa cells with transverse striations.

and bigibbous corolla but differs in having large oblate traps $(1.5-2.5 \mathrm{~mm})$ with a lateral mouth, traps confined to the expanded portion of the leaves, $1.5-2.5 \mathrm{~mm}$ long nonglandular trap appendages, terete brownish green peduncles, papillate scales, bracts and bracteoles, broad obovate upper lip of corolla, deep violet lower lip of corolla, shallowly trilobed upper lobe of stigma, globular capsules, terminal hilum, elongated overlapping testa cells with raised anticlinal boundaries and periclinal walls transversely striated.

Type: INDIA, Kerala, Kasaragod district, Koyithatta lateritic plateau, N 12 $19^{\prime} 43.7^{\prime \prime}$, E 075 15'11.9", 155 m, 12.07.2015, Biju \& Jomy 1008 (holo CAL; iso $\mathrm{MH}$ ).

Small, erect, terrestrial plants, 3.5-7 cm tall. Rhizoids 2-3 from the base of the peduncles, 6-20 $\times 0.1-0.4 \mathrm{~mm}$, tapering towards apex, branches capillary, distichous, pale purple, glandular. Stolons filiform, 15-25 mm long, 0.1-0.3 mm in thickness, internodes 3-3.5 mm long, branched. Leaves only on the stolons, 1 or 2 at the internodes, obovatespathulate, 3-nerved, 4.5-7 × 1.2-2.3 mm, rounded at apex. Traps oblate, $1.5-2.5 \times 1.2-1.6 \mathrm{~mm}$, found only on the lower side of expanded portion of the leaves, solitary, rarely two; stalk 0.1-0.2 mm long, attached at the longer side of the bladder, 0.3-0.8 $\mathrm{mm}$ apart from the mouth; mouth lateral, round; appendages two, subulate, 1.5-2.5 mm long, recurved, non-glandular. Racemes erect; peduncles 3.5-7 cm long, 0.3-0.5 mm thick, brownish green, terete, shallowly grooved on one side, glabrous.
Scales 3-4, adpressed on the peduncle, ovate, faintly 1-nerved, 1-1.5 × 0.7-1.2 mm, papillate. Bracts ovate, basifixed, 1.5-1.8 × 1-1.2 mm, nerves obscure, acute, papillate. Bracteoles 2, lanceolate, $0.8-1.2 \times 0.2-0.25 \mathrm{~mm}$, shorter than the bract, partially concealed, acute at apex, papillate. Flowers 1-4; pedicels 3-3.3 mm long, brownish-purple, winged, erect, recurved in fruit. Calyx lobes unequal; lower lobe ovate, smaller, 2.8-3 × 2-2.3 $\mathrm{mm}(3-3.5 \times 2.5-2.8 \mathrm{~mm}$ in fruit), brownish purple, papillate, emarginate at apex, faintly 11 -nerved; upper lobes ovate, $2.9-3.4 \times 2.2-2.8 \mathrm{~mm}$ (3.5-3.8 $\times 3.2-3.7 \mathrm{~mm}$ in fruit) brownish purple, faintly $11-$ nerved, persist in fruit, acute, papillate. Corolla violet, bi-lipped; upper lip 3-4 × 2.3-3.7 mm, broader than calyx lobe, obovate, rounded at apex, light purple with dark stripes; lower lip 3-4 mm across, broadly oblong or rectangular, narrowly bigibbous at middle with a flat rectangular yellowish region in between mouth and inflated region, palate ciliate, deep violet with a few purplish longitudinal striations on the inflated region; margins slightly undulate, $6-9 \times 4.5-6.5 \mathrm{~mm}$ when spread out; spur tubular, subulate, $4-5 \mathrm{~mm}$ long, light violet, slightly curved, acute, directed obliquely down wards, shorter than the lower lip of corolla. Stamens 2; filaments flattened, 1-1.2 $\times$ $0.2-0.25 \mathrm{~mm}$, truncate at apex, pale green; anther bithecous, dorsifixed, 0.5-0.6 × 0.25-0.3 mm, brownish, minutely papillate. Pistil $1.4-1.6 \mathrm{~mm}$ 
Table. 1. Diagnostic characters of Utricularia sainthomia, Utricularia malabarica and Utricularia lazulina.

\begin{tabular}{|c|c|c|c|}
\hline Characters & $\begin{array}{l}\text { U. sainthomia P.Biju, } \\
\text { Josekutty, Janarth. \& } \\
\text { Augustine }\end{array}$ & $\begin{array}{l}\text { U. malabarica Janarth. \& } \\
\text { A.N.Henry }\end{array}$ & U. lazulina P.Taylor \\
\hline Trap & $\begin{array}{l}\text { Located only on the ventral } \\
\text { side of the expanded portion } \\
\text { of the leaves, large sized, } \\
1.5-2.5 \mathrm{~mm} \text { across, oblate, } \\
\text { mouth lateral, appendages } \\
\text { long and non- glandular }\end{array}$ & $\begin{array}{l}\text { Located on stolons, stalk } \\
\text { and expanded portion of the } \\
\text { leaves,medium sized, } \\
0.9-1.5 \mathrm{~mm} \text { across, globose, } \\
\text { mouth basal, appendages } \\
\text { short and glandular }\end{array}$ & $\begin{array}{l}\text { Located on stolons, stalk and } \\
\text { expanded portion of the leaves, } \\
\text { medium sized } 0.7-1.2 \mathrm{~mm} \\
\text { across, sub-globose, mouth } \\
\text { basal, appendages short and } \\
\text { glandular }\end{array}$ \\
\hline $\begin{array}{l}\text { Scale, bract, } \\
\text { bracteole }\end{array}$ & Papillate & Papillae absent & Papillae absent \\
\hline Calyx & $\begin{array}{l}\text { Calyx lobes unequal, } \\
\text { brownish-purple }\end{array}$ & $\begin{array}{l}\text { Calyx lobes equal, } \\
\text { yellowish-green }\end{array}$ & $\begin{array}{l}\text { Calyx lobes unequal, } \\
\text { bluish-violet }\end{array}$ \\
\hline Upper lip of corolla & $\begin{array}{l}\text { Obovate, broader than } \\
\text { calyx lobe, light purple } \\
\text { with dark stripes }\end{array}$ & $\begin{array}{l}\text { Oblong, narrower than calyx } \\
\text { lobe, white-cream }\end{array}$ & $\begin{array}{l}\text { Oblong, narrower than calyx } \\
\text { lobe, bluish-violet }\end{array}$ \\
\hline Lower lip of corolla & $\begin{array}{l}\text { Deep violet, broadly oblong, } \\
\text { inflated portion deep violet }\end{array}$ & $\begin{array}{l}\text { Blue with white tinge, } \\
\text { sub-orbicular to obovate, } \\
\text { inflated portion white }\end{array}$ & $\begin{array}{l}\text { Blue, narrowly oblong to sub- } \\
\text { orbicular, inflated portion } \\
\text { white }\end{array}$ \\
\hline Spur & $\begin{array}{l}\text { Shorter than lower lip } \\
\text { of corolla, light violet }\end{array}$ & $\begin{array}{l}\text { Longer than lower lip } \\
\text { of corolla, white }\end{array}$ & $\begin{array}{l}\text { Shorter than lower lip } \\
\text { of corolla, violet }\end{array}$ \\
\hline Seed & $\begin{array}{l}\text { Obliquely ovoid, cylindrical, } \\
\text { hilum terminal, testa cells } \\
\text { longer, irregularly shaped, } \\
\text { junctions sinuate, periclinal } \\
\text { walls transversely striated }\end{array}$ & $\begin{array}{l}\text { Ovoid, hilum sub-terminal, } \\
\text { testa cells shorter, polygonal, } \\
\text { junctions angular, periclinal } \\
\text { walls smooth }\end{array}$ & $\begin{array}{l}\text { Obovoid, hilum sub-terminal, } \\
\text { testa cells shorter, polygonal, } \\
\text { junctions angular, periclinal } \\
\text { walls verrucose }\end{array}$ \\
\hline
\end{tabular}

long; ovary ovoid-globular, 0.8-0.9 × 0.7-0.8 mm; style short; stigma 2-lipped, lower lip semiorbicular and recurved, upper lip shallowly three lobed, middle lobe large. Capsules globular, 2-2.5 $\times 2-2.5 \mathrm{~mm}$, uniformly membranous; placenta globular 1.5-1.7 × 1.5-1.7 mm, dehisce by a vertical slit. Seeds obliquely ovoid-cylindrical, $0.3-0.35 \times$ $0.2-0.25 \mathrm{~mm}$, golden brown, testa cells elongated, irregular, margins raised and sinuate, periclinal walls transversely striated; hilum terminal.

Flowering \& fruiting: Flowering and fruiting from June to August.

Etymology: The species is named after the educational institution Saint Thomas College, Pala, Kerala, India, where one of the authors pursuing research work.

Distribution: Endemic to the lateritic plateau in Kerala, India.
Specimens examined: INDIA, Kerala, Kasaragod district, Adukkam, N $12^{\circ} 26^{\prime} 44.8^{\prime \prime}$, E $075^{\circ} 00^{\prime} 23.6^{\prime \prime}$, 102 m, 16.08.2015, Biju \& Jomy 1028; Ayampara, N 12²8'45.6", E 075¹3'15.9", 180 m, 18.08.2015, Biju \& Jomy 1045; Karindalam, N 12¹9'35.1", E 075 14'59.3", 187 m, 20.07.2016, Biju \& Jomy 1241; Kayyur, N 12¹6'25.1", E 075¹4'17.5", 96 m, 02.08.2016, Вiju \& Jomy 1250; Periya, N $12^{\circ} 28^{\prime} 09.2^{\prime \prime}$, E 07506'44.5", 85 m, 18.07.2016, Biju E Jomy 1230 (St. Thomas College Herbarium, Pala, Kerala, India); Kannur district, Peringome, N 12 04'06.7", E 075 ³6'83.9", 86 m 03.08.2016, Biju \& Jomy 1252 (CALI, St. Thomas College Herbarium, Pala, Kerala, India).

Conservation status: The new species has so far been known only from seven localities in Kasaragod and Kannur districts in Kerala, India. More extensive collections in similar habitats in other parts of 

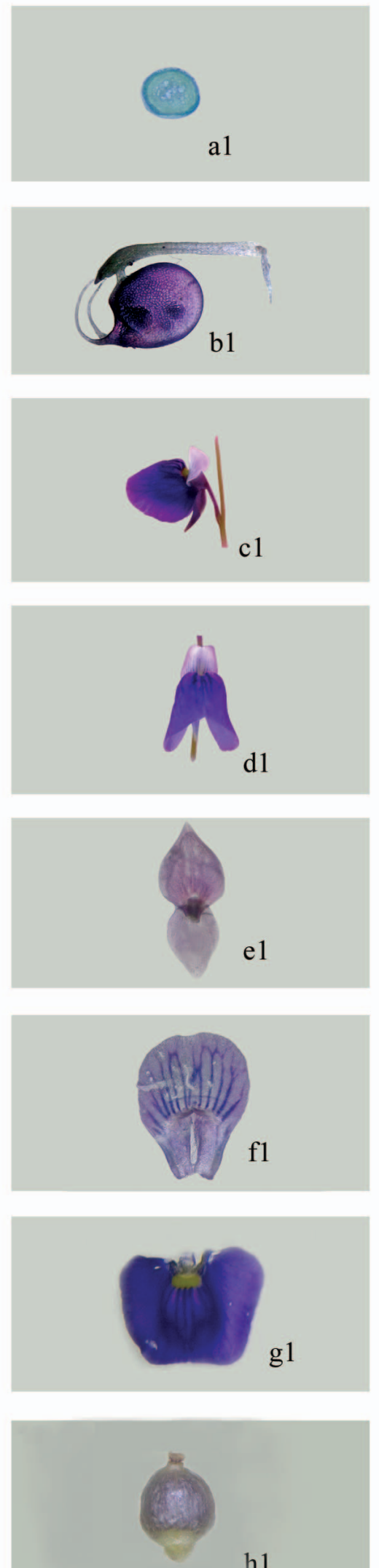

h1
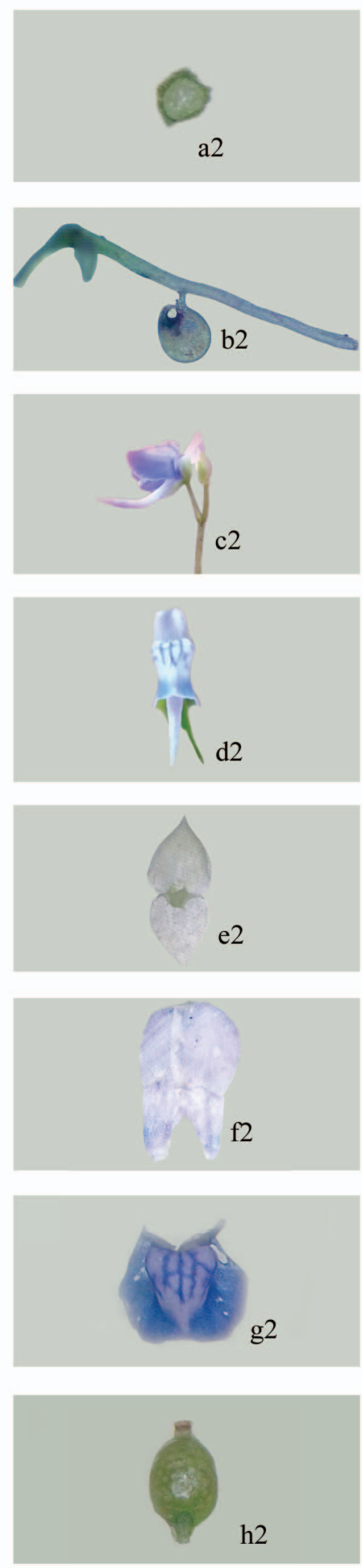
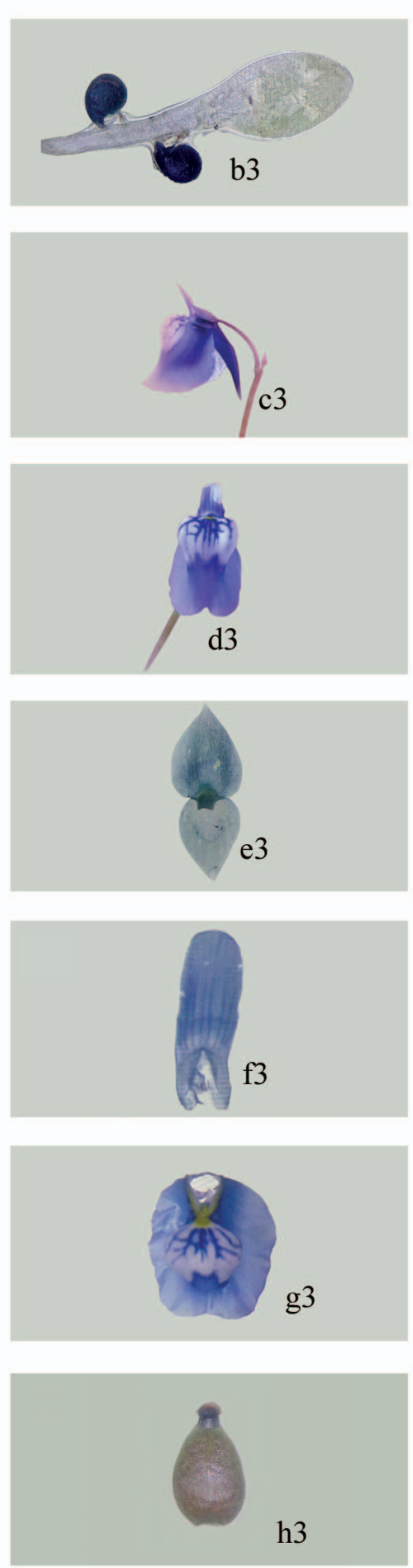

Fig. 4. Comparison of transverse section of scape, floral parts and capsule of Utricularia sainthomia with similar species: a1-h1. Utricularia sainthomia P.Biju, Josekutty, Janarth. \& Augustine; a2-h2. Utricularia malabarica Janarth. \& A.N. Henry; a3-h3. Utricularia lazulina P.Taylor. 
northern Kerala are needed to confirm its conservation status. However, there exist some threats as the populations are located near to laterite mining sites. Based on the available data, the species could be categorized as Data Deficient (DD) according to IUCN Criteria (2019).

Notes: This new species falls under U. sect. Oligocista based on leaf, trap, bract, flower and seed characters (Taylor, 1989). It is close to $U$. malabarica and $U$. lazulina but differs in many morphological characters (Table 1, Figure 4).

It also shows affinities with other species of this section such as $U$. cecilii P.Taylor, U. purpurascens J.Graham (U.arcuata Wight), U. praeterita P.Taylor and $U$. albocaerulea Dalzell in having tri-nerved leaves, basifixed bracts and broader upper lip of corolla, but differs in having large oblate traps with lateral mouth, traps which are located only on the expanded portion of the leaves, long (1.5-2.5 mm) and non-glandular trap appendages, papillate scales, bracts and bracteoles, deep violet corolla, globular capsule, elongated overlapping testa cells with raised anticlinal boundaries and periclinal walls transversely striated.

Key to the violet flowered species of Utricularia in India

1. Plants epiphytic; leaves orbicular ..... U. striatula

1. Plants terrestrial; leaves not orbicular. .. 2

2. Racemes twining..... 3

2. Racemes erect 4

3. Pedicels up to $4 \mathrm{~mm}$ long U. foveolata

3. Pedicels more than $4 \mathrm{~mm}$ long ... U. reticulata

4. Mouth of the trap terminal or lateral ........... 5

4. Mouth of the trap basal ................................... 7

5. Upper lip of the mouth beaked ..... U. caerulea

5. Upper lip of the mouth not beaked ............. 6

6. Leaves linear, 1-nerved ........................ U. hirta

6. Leaves peltate, dichotomously nerved U. pubescens
7. Racemes winged ........................................... 8

7. Racemes not winged ...................................... 10

8. Pedicels more than $6 \mathrm{~mm}$ long; recurved in fruit U. albocaerulea

8. Pedicels upto $5 \mathrm{~mm}$ long; erect or spreading in fruit

9. Spur upto $3.5 \mathrm{~mm}$ long: seeds obovoid U. lazulina

9. Spur 5-7 mm long; seeds ellipsoid

U. praeterita

10. Leaves 1-nerved U. polygaloides

10. Leaves 3-nerved 11

11. Fruiting pedicels recurved 12

11. Fruiting pedicels spreading or erect 13

12. Upper lip of the corolla oblong; spur extend beyond the lower lip U. malabarica

12. Upper lip of the corolla obovate; spur shorter than the lower lip U. sainthomia

13. Racemes angular 14

13. Racemes terete or grooved 15

14. Scales 1-nerved U. cecilii

14. Scales 3-nerved U. nayarii

15. Leaves spatulate U. smithiana

15. Leaves linear. 16

16. Pedicels not winged at anthesis ....... U. sunilii

16. Pedicels winged at anthesis. 17

17. Upper lip of corolla oblong, apex emarginate or truncate U. uliginosa

17. Upper lip of the corolla linear, apex rounded 18

18. Calyx with sub-equal lobes; capsule wall uniformly membranous U. wightiana

18. Calyx 2-lipped; capsule wall not uniformly thickened U. graminifolia 


\section{Acknowledgements}

The authors are thankful to Dr. Richard W. Jobson (Research Scientist, National Herbarium of New South Wales) for valuable suggestions about the new species; Principal, St. Thomas College, Pala, Kerala for providing facilities and Mr. Muhammed Haneef K.A., Research scholar Department of Applied Botany, Mangalore University for help. The first author is grateful to the Principal, Govt. College, Kasargod, Kerala for support. The first and second authors are thankful to University Grants Commission for financial support as UGC-FIP.

\section{Literature Cited}

BRIDSON D.M. \& L. FORMAN 1991. The Herbarium Handbook. Royal Botanic Gardens, Kew. p. 303.

FLEISCHMANN A. 2012. The new Utricularia species described since Peter Taylor's monograph. Carnivorous Plant Newsletter 41(2): 67-76.

IUCN 2019. Guidelines for using the IUCN red list categories and criteria. Version 14. Prepared by the Standards and Petitions Subcommittee. Available at: https:// nc.iucnredlist.org/redlist/content/attachment_files/ RedListGuidelines.pdf (Accessed on 06.14.2020).

JANARTHANAM M.K. \& A.N. HENRY 1992. Bladderworts of India. Botanical Survey of India, Kolkata. p. 174.

KUMAR V.V.N., PRABHUKUMAR V.M., JAGADEESAN R., HARINARAYANAN C.M., NAIR M.C., JANARTHANAM M.K \& I. BALACHANDRAN 2018. Utricularia sunilii (Lentibulariaceae), a striking new species from southern Western Ghats, Kerala, India. Phtyotaxa 371(2): 140-144. https://dx.doi.org./10.11646/ phytotaxa.371.2.9

SINDHU A., RAJU R., ARUNRAJ T., VISHNU W.K., BIJU P. \& V.N.S ANILKUMAR 2020. Utricularia kamarudeenii (Lentibulariaceae): a new species from Kerala, India. Phytotaxa 447(1): 068-072. https:// dx.doi.org./10.11646/phytotaxa.447.1.7

TAYLOR P. 1989. The genus Utricularia - A taxonomic monograph. Kew Bulletin additional series XIV. Her Majesty's Stationery Office, London. p. 724.

YADAV S.R., SARDESAI M.M. \& S.P. GAIKWAD 2000. Two new species of Utricularia L. (Lentibulariaceae) from Peninsular India. Rheedea 10: 107-112.

YADAV S.R., SARDESAI M.M. \& S.P. GAIKWAD 2005. A new species of Utricularia L. (Lentibulariaceae) from the Western Ghats, India. Rheedea 15: 71-73. 